The Journal of Animal \& Plant Sciences, 30(3): 2020, Page: 603-611

ISSN (print): 1018-7081; ISSN (online): 2309-8694

\title{
EFFECT OF STEAMING-UP PRIMIPAROUS NILI RAVI BUFFALOES ON SUBSEQUENT PRODUCTIVE AND REPRODUCTIVE PERFORMANCE
}

\author{
M. Saadullah ${ }^{1}$, Z. M. Iqbal' ${ }^{2}$ M. Imran ${ }^{3}$, M. N. Haque ${ }^{4}$ Hifzulrahman $^{1}$, J. A. Bhatti ${ }^{5}$, and M. Abdullah ${ }^{1 *}$ \\ ${ }^{1}$ Department of Livestock Production, University of Veterinary and Animal Sciences, Lahore; ${ }^{2}$ Cholistan University of \\ Veterinary and Animal Sciences, Bahawalpur; ${ }^{3} \mathrm{KBCMA}$ College of Veterinary and Animal Sciences Narowal, \\ University of Veterinary and Animal Sciences, Lahore; ${ }^{4}$ Department of Animal Nutrition, University of Veterinary and \\ Animal Sciences, Lahore; ${ }^{5}$ College of Veterinary and Animal Sciences, Jhang, University of Veterinary and Animal \\ Sciences, Lahore \\ *Corresponding author's e-mail: mabdullah@uvas.edu.pk
}

\begin{abstract}
Improved feeding during pre-calving phase affects the Body Condition Score (BCS) that subsequently dictate the postcalving productive and reproductive performance. The objective of this study was to investigate the effect of three levels of concentrate supplementation [0.5, 1.0 and $1.5 \%$ of body weight (BW)] during pre-calving period on post-calving reproductive and lactation performance in Nili Ravi buffalo heifers. Twenty-six pregnant Nili-Ravi buffalo heifers at 150 \pm 20 [Mean \pm standard deviation (SD)] days in pregnancy with $(\mathrm{BW}=516 \pm 57 \mathrm{KG}, \mathrm{BCS}(1-5)=3.98 \pm 0.18)$ were selected and divided into three treatment groups; Low $(n=8)$, Medium $(n=9)$ and High $(n=9)$ and allocated three dietary treatments. The treatments were basal diets composed of green fodder [dry matter $(\mathrm{DM})=2.0 \%$ of body weight $(\mathrm{BW})$ ] with three levels of Concentrates $(\mathrm{CP}=20.9 \%, \mathrm{ME}=2.62 \mathrm{Mcal} / \mathrm{kg}$ ) i.e. 0.5 (Low), 1.0 (Medium), and 1.5\% (High) of the $\mathrm{BW}$. The animals received same feed (forage DM at the rate of $2 \%$ of BW and concentrate at $0.5 \mathrm{~kg}$ per liter of milk produced on as fed basis) after calving. Increasing concentrate supplies from 0.5 to $1.5 \%$ of BW increased pre-calving dry matter intake (DMI), however, it didn't affect BW and BCS at calving. Increased concentrate supply at $1.5 \%$ of BW resulted in decrease in post calving conception rate to $33 \%$ as compared to 75 and $77.8 \%$ at 0.5 and $1.0 \%$ of $\mathrm{BW}$ concentrate supply. The treatment High decreased lactation length $(15 \%)$ and yield $(17 \%)$ as compared to Low and Medium treatment. Pre-calving supplementation of concentrate beyond $0.5 \%$ of BW showed no improvement of postcalving productive and reproductive performance. In the given dietary situation, the Nili Ravi heifers didn't require more than $0.5 \%$ of BW concentrate along with $2.0 \%$ of BW green fodder DM during post 150 days of pregnancy.
\end{abstract}

Key words: Buffalo, concentrate, lactation, Nili Ravi, reproduction, Steaming-up https://doi.org/10.36899/JAPS.2020.3.0071

Published online March 25, 2020

\section{INTRODUCTION}

Buffalo (Bubalus bubalis) are known for their ability to effectively utilize poor quality feed resources through efficient rumen fermentation (Wanapat et al., 2013) as well as better nitrogen utilization (Neglia et al., 2014). However, imbalance and insufficient nutrients' supply resulted in low milk production, poor growth, delayed maturity, high mortality rates and poor reproductive performance of buffalo (Talib and Herawati, 2014; Sarwar et al., 2009; Pasha, 2013). This is especially true when it comes to the nutrition of cow during the period of late pregnancy and early lactation (commonly referred as transition period). In literature, research conducted in dairy cow showed that the energy levels in the transition cow diet plays an important role in post calving productive performance (Janovick et al. 2011; Roche et al. 2015). Variation in energy supplies leads to changes in the BCS during this period. Improved BCS due to increased supplementation of pre-calving feeding can increase post-calving milk and milk components (Gobikrushanth et al, 2019). Contrary to this, a high BCS at calving could lead to greater degree of fat mobilization during post-partum period (Gheise et al. 2017), which could lead to several metabolic disorders mainly ketosis, prolonged service period and calving interval (Roche et al. 2015; Chen et al. 2015) Furthermore, post-calving reproductive performance is affected by pre (Singh et al., 2009) and post-calving (Patton et al., 2007) BCS. Optimum energy supplies at pre-partum period are critical to achieve desirable BCS (Delfino et al, 2017). As per our knowledge the dairy buffalo in general and for primiparous in specific, limited studies are available to define the total nutrient requirements during prepartum period. The objective of the current study was to determine the level of concentrate supplementation for steaming-up of primiparous buffaloes and its impact on BCS around calving and its effect on post calving productive and reproductive performance. 


\section{MATERIALS AND METHODS}

Animals, Experimental Design, and Diets: The experiment was carried out at Buffalo Research Institute (BRI), Pattoki-Pakistan. All the procedures were followed in accordance with the guidelines set out by the ethical committee of University of Veterinary and Animal Sciences (UVAS), Lahore- Pakistan (ORIC2014). Twenty-six pregnant Nili-Ravi buffalo heifers at $150 \pm 20$ [Mean \pm standard deviation (SD)] days in pregnancy with $\mathrm{BW}=516 \pm 57 \mathrm{KG}$ and $\mathrm{BCS}(1-5)=3.98 \pm$ 0.18 were selected and divided into three groups $(\mathrm{n}=8$, 9, 9) and allocated three dietary treatments. The treatments were basal diets composed of green fodder $[$ dry matter $(\mathrm{DM})=2.0 \%$ of body weight $(\mathrm{BW})]$ with three levels of concentrates i.e. 0.5 (Low), 1.0 (Medium), and $1.5 \%$ (High) of BW. The green fodder included chopped corn and sorghum during pre-calving period and corn, berseem, and oats during lactating period. All buffaloes were fed similar diet after calving (forage DM (a) 2\% of BW and concentrate @ $0.5 \mathrm{~kg}$ per liter of milk produced on as fed basis close to requirements defined by Paul et al. (2002). Feed allowances for individual animals were calculated and measured quantity of feed was offered individually to the animals of all the groups. For fodder quantity, adjustments were made twice a month. Feed was offered twice a day (morning and evening) and orts were collected and weighed next morning, and intake of fodder and concentrate for each animal recorded. The daily DMI was calculated on the basis of DM of fodder, concentrate and orts determined in the lab. The nutrient composition and ingredient percentage of concentrates fed during the gestation and lactation periods is presented in Table 1 and composition of fodders used in experiment is presented in Table-2. The nutritional values of concentrate mix and fodder presented in Table-1 and Table- 2 are obtained by analyzing samples in the animal Nutrition Lab of BRI except ME [ME = calculated from the ingredients' gross energy by using energy conversion calculator of University of California, Davis] and NFC $[\mathrm{NFC}=$ non fiber carbohydrates, $(100-(\mathrm{CP}+\mathrm{NDF}+$ crude ash + crude fat))] which is calculated using formula. All the animals were housed in individual tie-stalls, naturally ventilated, sloped concrete floored house. Animals were kept in one shed under same roof having separate pen \& mangers to ensure individual feeding. Free access to drinking water was ensured in individual rubber tubs; filled twice daily with fresh clean water.

Measurements and Sampling: All the animals were weighed using digital weighing scale (YAOHUA YH-T3) before the start of experiment and during experiment on fortnightly intervals early in the morning before feed distribution. The animals were examined for BCS according to the method of Anitha et al. (2011) using 1-5 scoring system on eight body regions of buffalo. The initial BW and BCS was $516 \pm 57 \mathrm{KG}$ and $3.98 \pm 0.18$ respectively. After the parturition, animals were regularly observed for heat signs. Teaser bull was also used twice daily for heat detection. Animals in heat were detected and period from parturition to first heat recorded as postpartum oestrus interval (PPOI). The animals in heat (mucus discharge and stand to be mounted) were inseminated and each insemination recorded as service. The pregnancy diagnosis was done after 60 days through rectal palpation and ultrasonography (Honda-510), after pregnancy confirmation the period from parturition to successful service was calculate and recorded as service period. Feed samples from each batch of concentrate mix and fodder used in the experiment were collected and analyzed. Feed samples were dried at $55^{\circ} \mathrm{C}$, ground to 1 $\mathrm{mm}$ size for proximate analysis. The DM and EE contents were determined following AOAC official methods 7.008 and 7.045 respectively (AOAC, 2005). The NDF and $\mathrm{ADF}$ analyses were performed by the sequential procedure of Van Soest et al. (1991) Total nitrogen was determined by Kjeldahl analysis (AOAC, 2005; method 2.055). Buffaloes were milked twice daily (0400 and $1600 \mathrm{hrs}$.). Hand milking method was adopted to harvest milk from buffaloes. Milk yield was recorded at each milking on daily basis. Lactation length calculated from date of parturition to date of drying and yield were recorded for each animal. Fat corrected Milk was calculated using the formula developed by Tyrrell and Reid. (1965) and energy corrected milk method of Rico et $a l$, (2014). Samples of milk from individual animals were collected on each 14th day and analyzed for milk components (fat, protein, solid not fat (SNF)) through infrared analysis using milk analyzer (Lactoscan, Lactostar-3510) (Ahmad et al. 2019).

Statistical Analysis: Data were condensed to weekly means for variables recorded daily before conducting the statistical analysis. Data were analyzed using MIXED procedure of SAS University Edition (SAS Institute Inc., Cary, NC; 2018). The variables that were measured over time (BW, BCS, DMI, milk yield, and milk components) were further analyzed with REPEATED measure analysis statement. When a significant effect $(\mathrm{P} \leq 0.05)$ of dietary treatment was observed, means were compared using the Tukey's test for all results.

\section{RESULTS}

The interaction between treatment and week was not significant in any of the parameters; hence, their results are not presented.

Dry Matter Intake: The DMI followed the treatments during pre-calving period as the total dry matter intake (TDMI) and concentrate dry matter intake (CDMI) were highest in treatment High and decreased in Medium and Low treatments $(\mathrm{P}<0.01)$, whereas, forage dry matter 
intake (FDMI) was not affected across the whole range of treatments (Table-3). The post-calving total, forage, and concentrate DMI was not affected during first eight weeks as well as in the whole lactation with the treatments (Table-3; $\mathrm{P}>0.5$ ).

Body Weight and Condition: Average daily gain was not different among the treatments Low, Medium and High during pre-calving, during first eight weeks of lactation, and during whole lactation period (Table-4). Body condition score at the time of calving, pre-calving and post-calving were not different among the treatment groups (Table-4).

Milk and Milk Component Yield: Milk yield was not affected by the treatments Low, Medium and High during early lactation (first eight weeks of lactation) and complete lactation period (Table-5). The lactation length was 44 and 54 days longer in treatment Low and Medium as compared to treatment High (Table-6). Milk component yield was not different across the treatments during early lactation and complete lactation period (Table-5).

Post-calving Reproductive Performance: Birth weight of calves was not affected by the treatments $(\mathrm{P}>0.05)$. However, numerically the calves produced by heifers on treatment High had higher birth weight as compared to Low and Medium treatments. Similarly, post-partum estrus interval, service period and services per conception were not affected by the treatments (Table-6). Treatment High resulted in decrease in post calving conception rate to $33 \%$ as compared to 75 and $77.8 \%$ at Low and Medium.

\section{DISCUSSION}

The objective the current study was to investigate the increasing levels of concentrate supplementation during pre-calving period on BCS around calving and its impact on post calving productive and reproductive performance of dairy buffalo heifers.

Dry Matter Intake: In pre-calving period, the increased TDMI and CDMI with increasing concentrate supply from Low to High treatment was in agreement with the findings of previous studies (Galic. 2017; Zhang et al., 2015). The increasing nutrient density of the diet with the increasing ratio of concentrate from Low to High resulted in increased TDMI (Singh et al., 2003). Literature showed that increased density of the diet improves the palatability and therefore increase the DMI (Gaafar et al., 2009; Little et al., 2017). However, the results of increasing dietary energy levels on the DMI are inconsistent as it has been shown to increase (Zhang et al., 2015) or having no effect on the prepartum DMI. There was no effect of varying levels of concentrate in pre-partum period on post-partum DMI, the prepartum supplementation of energy or protein concentrate have no carry over effect on postpartum DMI (Stockdale, 2005). Ryan et al. (2003) also reported neutralization of postpartum DMI (15.0 kg/head and $15.2 \mathrm{~kg} / \mathrm{head})$ in prepartum supplemented (adlib-silage + concentrate $3 \mathrm{~kg} / \mathrm{d}$ ) vs non-supplemented (ad-lib silage) group of cows. The concentrate supplemented cows during prepartum period had advantage over non-supplemented cows for DMI during postpartum period due to adaptation of rumen for starch and papillae development (Samuel, 2016), but in this study there was no non-supplemented group so no difference in postpartum DMI might be due to the fact that all heifer had some concentrate in their prepartum diet so equally adaptive for postpartum DMI. Nevertheless, none of the study reported a negative effect of feeding prepartum concentrate on post-partum DMI.

Body Weight and Body Condition Scores: Interestingly, there was no change in body weight and BCS at calving, during pre-calving period, during first eight weeks of lactation and during whole lactation period across whole range of treatments. Similarly, previous studies showed that with the changing supplementation levels of concentrate, there was no change in BW during pre-partum period ( Meeske et al., 2006). While Mithuna et al. (2015) found improvement in BCS and BW in concentrate supplemented vs non supplemented group. The difference in results from present study was due to the difference in initial BCS (2.70 to 2.92). The initial weight and BCS in present study was $(\mathrm{BW}=516, \mathrm{BCS}=3.98)$ higher as compared to previous studies additionally the supplementation was done in primiparous heifers in the current study whereas no such study as per author review exist in literature. Moreover, the high BCS at calving in our study (3.80) compared to literature (2.73) could be due to the wide difference in diets. For example, in the study of Ryan et al. (2003) the cows were compared with a concentrate fed vs. no concentrate treatment that was different compared to our strategy. The heifers enrolled in present study were already at higher BCS (3.98) and weight (86\% of adult weight) so, during the concentrate supplementation period all the groups tend to maintain the BCS. However, the increase in BW at calving (numerically higher in treatment High) observed in all groups. All this explains why we observed different results compared to literature. However, it is important to note that there is a loss in BW of $80 \mathrm{~kg}$ on an average from -3 weeks to first 8 weeks of calving in all treatments. Zhang et al. (2015) also reported loss of BW (-13.8 vs. $-27.7 \mathrm{~kg})$ due to negative energy balance during lactating period in both groups fed either higher energy diet $(1.55 \mathrm{Mcal} / \mathrm{kg})$ during prepartum period or low $(1.25 \mathrm{Mcal} / \mathrm{kg})$ energy diet. Similarly, Straten et al. (2009) reported more than 7\% loss in $\mathrm{BW}$ at $10 \mathrm{~d}$ of lactation regardless of pre-calving 
feeding regimen. The loss in BCS during early lactation was 3 times greater in cows having $\mathrm{BCS} \geq 4$ at calving as compared to $\mathrm{BCS} \leq 3.5$ (Gheise et al. 2017). Cross bred dairy cows fed beyond requirements (NRC1989+20\%) during pre and post calving period had higher body weight at calving (486 vs. $517 \mathrm{~kg}$ ) but had similar BW loss trend (71 vs. 76) at 45 day of lactation compared to restricted fed (80\% of NRC1989) group (Singh et al. 2003). The excessive mobilization of body fat leads to higher oxidative stress in buffaloes with higher BCS around calving (Delfino et al, 2017). The cows with extreme BCS loss during postpartum period had reduced fertility but improved milk production (Gobikrushanth et al, 2019).

Milk and Milk Components Yield: Daily Milk yield was not different among the treatments during early (first eight weeks of lactation) and complete lactation period. Increasing the nutrient density during pre-partum period has been shown to have either no effect (Galic. 2017; Yi et al., 2015), decreased, or increased (Mithuna et al., 2015) the milk production. There are several factors that could explain such differences. Firstly, the amount concentrate fed in the current study in the Low treatment could be sufficient enough for the post-partum production responses. For example, in the study of Mithuna et al. (2015) they compared the effects of feeding $2 \mathrm{~kg}$ concentrate with non-supplemented animals and observed an increase in milk yield. In our study, the Low treatment heifers received $2.37 \mathrm{~kg}$ concentrate, an amount already greater compared to the feeding of Mithuna et al. (2015). The study where milk production decreased with high concentrate feeding such as Holcomb et al. (2001), the forage-to concentrate ratio was too low (30\% forage) that could create a negative effect because of ruminal acidosis. Gheise et al, 2017 reported that the cows with higher BCS at calving had higher mobilization of fat reserves as compared to Low BCS cows but improved milk production. Similarly, Gobikrushanth et al. (2019) reported extreme BCS loss during postpartum period had reduced fertility but improved milk production. Interestingly, the lactation length was 44 and 54 days lengthier in treatment Low and Medium as compared to treatment high (Table 5). The possible explanation to this increase is that 2 heifers died in the treatment High group during the lactating phase, so due to incomplete lactations the average lactation length of treatment High was less compared to the other treatments. Milk components' yield was not different among the treatments Low, Medium and High during early lactation (first eight weeks of lactation) and complete lactation period (Table 4) in agreement with the study conducted by Mithuna et al. (2015). Ayaşan et al. (2012-b) also found no difference between low, medium and high BCS groups for milk components except lactose and urea. Contrary to our findings, studies conducted by Beyero et al. (2015) and Yi et al. (2015) reported decrease in milk fat contents with the increased concentrate to roughage ratio, whereas, milk CP and SNF remained unaffected. Changes in milk solids and especially fats are associated with the degree of mobilization of fat reserves (Galic., 2017) in the early lactation and somatic cell count (Ayaşan et al. 2011). In a study by Meeske et al. (2006), cows fed ration containing $9 \mathrm{~kg}$ per day concentrate had higher butter fat compared to others. Similarly, postcalving dietary strategy could also impact the milk components. Cows fed diet above NRC recommendation $(\mathrm{NRC} 1989+20 \%)$ in pre and post-partum stage had higher milk fat, SNF and total solid (Singh et al., 2003), however, protein and lactose were not affected by treatments.

Birth Weight of Calves: Increased concentrate ratio in the diet in pre-partum duration didn't change the calf birth weight which is in agreement with the previous studies (Bayemi et al., 2008). Contrary to this, Mithuna et al. (2015) reported that pre-partum concentrate supplementation $(2 \mathrm{~kg} / \mathrm{d})$ had higher $(24.33 \mathrm{vs} .28 .00 \mathrm{~kg})$ birth weight of buffalo calves as compared to nonsupplemented group. This contradiction might be due to fact that BCS of buffaloes during gestation and at calving was higher in present study, as the higher BCS at mating and during pregnancy results in higher birth weight and return rate compared to thin (Low BCS) animals (Cam et al. 2018). Moreover, birth weight of calves in our study were also higher (ranged 30.3 to 33.5 ) compared to the study by Mithuna et al. (2015) and close to the birth weight reported by Naqvi and Shami (1999) in Nili Ravi buffalo calves. Similarly, Abdulkareem et al. (2012) reported that feeding $7 \mathrm{~kg} / \mathrm{d}$ of concentrate resulted in higher calves birth weight ( 43 vs. $32 \mathrm{~kg}$ ) compared to no supplemented group. As in the current study, we did not create a non-supplemented group, hence; the results of our study could not be directly compared with those studies.

Post-partum Oestrus Interval and Services per Conception: Post-partum oestrus interval and services per conception were also remained unaffected among different treatments, however: the number of animals conceived were higher in treatment Low and Medium as compare to treatment High. The previous studies (Ayaşan et al. 2012-a; Obese et al. 2011) reported that conception rate, pregnancy percentage and service period were not affected by concentrate supplementation and BCS. The positive effect of increasing energy and protein supply has been reported to improve the reproductive performance in mostly starved or underfed (low BCS) animals such as reported by Abdulkareem et al. (2012) and Mithuna et al. (2015). Pereira et al. (2018) also reported that the conception rate $(69.75 \%)$ found greater in cows with moderate BCS (between 2.75-4.0) than thin cows $(32.98 \%)$ with low (BSC of 2.0-2.5). Otherwise, 
increased protein and energy supplies beyond requirements are negatively correlated with postpartum oestrus and ovulation (Qureshi et al., 2002). This further explains why in our study, only 3 animals conceived in High treatment compared to 7 conceived in Low and Med group. The study conducted by Janovick et al. (2011) where they fed 80\% (low), 100\% (restricted) and 150\% (high) of NRC requirements during pre-partum period found that feeding above NRC requirements resulted into increased mobilization of fat reserves and incidence of metabolic disorders as compared to restricted and under low fed cows during pre-partum period. Tanemura et al. (2016) reported that with the increase in fat deposition rate $(60 \%$ or higher) on liver increases the death or culling rates $(69.7 \%)$ and also increased the ovarian disease recurrence rates $(84.9 \%)$. This further explains why in our study the low pregnancy rate and higher mortality observed in treatment High.

Table 1. Ingredient and nutrient composition of concentrates used in the study.

\begin{tabular}{|c|c|c|}
\hline \multirow{2}{*}{ Ingredients } & Pregnant buffalo concentrate & Lactating buffalo concentrate \\
\hline & \multicolumn{2}{|c|}{$\mathrm{g} / 100 \mathrm{~g}$} \\
\hline Soybean meal & 0 & 3.50 \\
\hline Canola meal & 15.0 & 15.0 \\
\hline Cottonseed cake & 10.0 & 9.0 \\
\hline Rice polish & 16.0 & 16.0 \\
\hline Wheat bran & 20.0 & 18.0 \\
\hline Corn grains & 23.5 & 21.5 \\
\hline Sugarcane molasses & 12.5 & 12.0 \\
\hline Sodium bicarbonate & 1.0 & 1.0 \\
\hline Mineral premix & 1.0 & 1.0 \\
\hline Megalac $^{1}$ & 0 & 2.0 \\
\hline Urea & 1.0 & 1.0 \\
\hline \multicolumn{3}{|l|}{ Nutritive values* } \\
\hline Dry matter, \% & 85.6 & 86.6 \\
\hline $\mathrm{CP}, \%$ & 19.05 & 20.8 \\
\hline $\mathrm{ME}^{2}, \mathrm{Mcal} / \mathrm{kg}$ & 2.62 & 2.71 \\
\hline Crude fibre, $\%$ & 8.74 & 8.48 \\
\hline $\mathrm{NFC}^{3}, \%$ & 37.6 & 46.1 \\
\hline $\mathrm{EE}^{4}, \%$ & 5.5 & 9.00 \\
\hline \multicolumn{3}{|c|}{$\begin{array}{l}{ }^{2} \mathrm{ME}=\text { calculated from the ingredients' gross energy by using energy conversion calculator of University of California, Davis } \\
{ }^{3} \mathrm{NFC}=\text { non fiber carbohydrates, }(100-(\mathrm{CP}+\mathrm{NDF}+\text { crude ash }+ \text { crude fat }))\end{array}$} \\
\hline
\end{tabular}

Table 2. Nutrient composition of fodders used in the study.

\begin{tabular}{|c|c|c|c|c|}
\hline & \multicolumn{4}{|c|}{ Experimental phase } \\
\hline & \multicolumn{2}{|c|}{ Pre-Calving } & \multicolumn{2}{|c|}{ Post-Calving } \\
\hline & Sorghum & Maize & Berseem & Oats \\
\hline Dry matter \% & 27.3 & 23.1 & 15.6 & 26.9 \\
\hline Crude protein $\%$ & 7.52 & 7.11 & 19.91 & 7.2 \\
\hline $\mathrm{EE}^{1} \%$ & 1.81 & 1.93 & 2.64 & 2.08 \\
\hline Crude fiber $\%$ & 31.2 & 33.4 & 18.6 & 24.4 \\
\hline $\mathrm{NDF}^{2} \%$ & 56.1 & 65.2 & 47.3 & 56.1 \\
\hline $\mathrm{ADF}^{3} \%$ & 33.6 & 35.2 & 28.3 & 32.1 \\
\hline Ash $\%$ & 9.38 & 7.92 & 12.2 & 11.2 \\
\hline $\mathrm{NFC}^{4} \%$ & 25.2 & 17.8 & 17.9 & 23.4 \\
\hline
\end{tabular}


Table 3. Dry mater intake of first calf Nili Ravi buffalo heifers during pre and post-calving period.

\begin{tabular}{|c|c|c|c|c|c|c|}
\hline \multirow{2}{*}{$\begin{array}{l}\text { Dry matter intake, } \\
\mathrm{kg} / \mathrm{d}\end{array}$} & \multicolumn{3}{|c|}{ Treatments } & \multirow{2}{*}{ SEM } & \multicolumn{2}{|c|}{$p$ value } \\
\hline & Low & Medium & High & & Treatment & Weeks \\
\hline \multicolumn{7}{|c|}{ Pre-calving (-21 weeks) } \\
\hline Total & $12.3^{\mathrm{a}}$ & $14.1^{\mathrm{ab}}$ & $15.4^{\mathrm{b}}$ & 0.74 & $<0.01$ & $<0.01$ \\
\hline Fodder & 9.92 & 9.56 & 9.4 & 0.52 & 0.76 & $<0.01$ \\
\hline Concentrate & $2.37^{\mathrm{a}}$ & $4.54^{b}$ & $5.97^{\mathrm{c}}$ & 0.34 & $<0.01$ & $<0.01$ \\
\hline \multicolumn{7}{|l|}{ Pre-calving (-3 weeks) } \\
\hline Total & $12.3^{\mathrm{a}}$ & $13.3^{\mathrm{b}}$ & $13.6^{\mathrm{b}}$ & 0.85 & 0.43 & $<0.01$ \\
\hline Fodder & 9.92 & 8.76 & 8.32 & 0.78 & 0.42 & 0.22 \\
\hline Concentrate & $2.37^{\mathrm{a}}$ & $4.55^{\mathrm{bc}}$ & $5.31^{\mathrm{c}}$ & 0.40 & $<0.01$ & $<0.05$ \\
\hline \multicolumn{7}{|c|}{ Post-calving (complete lactation) } \\
\hline Total & 14.3 & 14.4 & 14 & 0.37 & 0.63 & $<0.01$ \\
\hline Fodder & 10.8 & 10.9 & 11.1 & 0.22 & 0.64 & $<0.01$ \\
\hline Concentrate & 3.49 & 3.52 & 2.93 & 0.28 & 0.23 & $<0.01$ \\
\hline \multicolumn{7}{|c|}{ Post-calving ( 8 weeks) } \\
\hline Total & 12.2 & 13.1 & 13.4 & 0.77 & 0.56 & $<0.05$ \\
\hline Fodder & 8.5 & 9.07 & 9.67 & 0.59 & 0.41 & 0.65 \\
\hline Concentrate & 3.73 & 4.02 & 3.76 & 0.30 & 0.74 & $<0.01$ \\
\hline
\end{tabular}

Table 4. Body weight and body condition score during pre and post-calving stage.

\begin{tabular}{|c|c|c|c|c|c|c|}
\hline \multirow{3}{*}{ Item } & \multicolumn{3}{|c|}{ Treatments $^{1}$} & \multirow{3}{*}{ SEM } & \multicolumn{2}{|c|}{$p$ value } \\
\hline & Low & Medium & High & & Treatment & Weeks \\
\hline & \multicolumn{5}{|c|}{ Pre-calving (-21 weeks) } & \\
\hline Body Weight (Kg) & 550.00 & 564.00 & 576.00 & 19.0 & 0.61 & $<0.01$ \\
\hline $\operatorname{BCS}(1-5)$ & 3.81 & 3.80 & 3.83 & 0.05 & 0.91 & $<0.01$ \\
\hline \multicolumn{7}{|c|}{ Pre-calving (-3 weeks) } \\
\hline Body Weight (Kg) & 575.00 & 593.00 & 611.00 & 20.9 & 0.47 & $<0.01$ \\
\hline $\operatorname{BCS}(1-5)$ & 3.84 & 3.79 & 3.86 & 0.08 & 0.81 & $<0.01$ \\
\hline \multicolumn{7}{|c|}{ Post-calving (complete lactation) } \\
\hline Body Weight (Kg) & 477.00 & 502.00 & 496.00 & 16.4 & 0.51 & $<0.01$ \\
\hline $\operatorname{BCS}(1-5)$ & 3.50 & 3.49 & 3.57 & 0.07 & 0.66 & $<0.01$ \\
\hline \multicolumn{7}{|c|}{ Post-calving ( 8 weeks) } \\
\hline Body Weight (kg) & 490.00 & 520.00 & 530.00 & 19.0 & 0.31 & $<0.01$ \\
\hline $\operatorname{BCS}(1-5)$ & 3.65 & 3.64 & 3.75 & 0.08 & 0.52 & $<0.01$ \\
\hline
\end{tabular}

Table 5. Milk and milk components' yield in first lactation of Nili Ravi buffaloes.

\begin{tabular}{|c|c|c|c|c|c|c|}
\hline \multirow[b]{2}{*}{ Item } & \multirow[b]{2}{*}{ Low } & \multicolumn{2}{|c|}{ Treatments $^{1}$} & \multirow{2}{*}{ SEM } & \multicolumn{2}{|c|}{$p$ value } \\
\hline & & \multicolumn{2}{|c|}{ complete lactation } & & Treatment & Weeks \\
\hline Milk $^{1}$ & 7.37 & 7.22 & 6.56 & 0.54 & 0.49 & $<0.01$ \\
\hline $\mathrm{FCM}^{2}$ & 11.4 & 10.7 & 9.85 & 0.89 & 0.44 & $<0.01$ \\
\hline $\mathrm{ECM}^{3}$ & 11.27 & 10.69 & 9.62 & 0.84 & 0.40 & $<0.01$ \\
\hline Fat $\%$ & 6.87 & 6.53 & 6.66 & 0.25 & 0.61 & $<0.05$ \\
\hline Protein \% & 4.14 & 4.16 & 4.02 & 0.12 & 0.62 & $<0.01$ \\
\hline Lactose $\%$ & 5.36 & 5.39 & 5.20 & 0.13 & 0.47 & $<0.01$ \\
\hline \multicolumn{7}{|c|}{ early lactation ( 8 weeks) } \\
\hline Milk $^{1}$ & 8.84 & 9.06 & 8.44 & 0.75 & 0.81 & $<0.01$ \\
\hline
\end{tabular}




\begin{tabular}{|c|c|c|c|c|c|c|}
\hline $\mathrm{FCM}^{2}$ & 14.1 & 13.4 & 13.0 & 1.51 & 0.85 & $<0.01$ \\
\hline $\mathrm{ECM}^{3}$ & 13.8 & 13.4 & 12.8 & 1.36 & 0.85 & $<0.01$ \\
\hline Fat $\%$ & 7.18 & 6.33 & 6.72 & 0.54 & 0.50 & $<0.01$ \\
\hline Protein \% & 4.28 & 4.32 & 4.49 & 0.33 & 0.88 & 0.12 \\
\hline Lactose \% & 5.66 & 5.59 & 5.35 & 0.35 & 0.79 & 0.13 \\
\hline
\end{tabular}

Table 6. Post calving reproductive and first lactation performance of Nili Ravi heifers.

\begin{tabular}{|c|c|c|c|c|c|}
\hline \multirow{2}{*}{ Parameter } & \multicolumn{3}{|c|}{ Treatment $^{1}$} & \multirow{2}{*}{ SEM } & \multirow{2}{*}{$p$ value } \\
\hline & Low & Medium & High & & \\
\hline Weight at calving $(\mathrm{Kg})$ & 565 & 555 & 625 & 28.0 & 0.13 \\
\hline Age at calving (Days) & 1039 & 1101 & 1144 & 44.0 & 0.23 \\
\hline Calf birth weight (kg) & 30.3 & 33.1 & 33.5 & 1.36 & 0.12 \\
\hline $\mathrm{PPOI}^{2}$ & 129 & 89.9 & 101 & 16.0 & 0.25 \\
\hline Service period & 133 & 136 & 128 & 19.0 & 0.21 \\
\hline Services per conception & 3.29 & 2.75 & 4.14 & 0.74 & 0.41 \\
\hline Lactation length (Days) & 327 & 335 & 282 & 16.0 & $<0.05$ \\
\hline Lactation yield & 2345 & 2322 & 1905 & 174 & 0.12 \\
\hline Number of buffaloes conceived after calving & 7 & 7 & 3 & - & - \\
\hline Mortality & - & - & 2 & - & - \\
\hline
\end{tabular}

${ }^{1}$ Low $=$ concentrate supplementation @ $0.5 \%$ of BW; Medium = concentrate supplementation @ 1.0\% of BW; High = concentrate supplementation@1.5\% of BW. ; ${ }^{2}$ Postpartum oestrus interval; Level of significance $\mathrm{P}<0.05$.

Conclusion: The current study showed no effect of increasing pre-calving intake of concentrate on BW and $\mathrm{BCS}$ at calving and post-calving period. Milk yield and milk composition were not affected by the treatments. However, high mortality due to metabolic stress and low pregnancy rates was observed in the High treatment. In the current dietary situation, feeding concentrate above $2.5 \mathrm{~kg} /$ day (or $0.5 \%$ of the body weight) to heifers at BCS 4 during advanced pregnancy has no benefit on productive and reproductive performance. Further studies are needed to evaluate the effects of feeding concentrate at similar levels to low BCS heifers or levels below $2.5 \mathrm{~kg}$ to $\mathrm{BCS} \geq$ 4 heifers to improve the precision.

\section{REFERENCES}

Abdulkareem, T.A., S.A. Al-Sharifi, S.M. Eidan, and R.G. Sasser (2012). Reproductive and productive performance of Iraqi buffaloes as influenced by pre-mating and pre-calving concentrate supplementation. Pakistan Vet. J. 32(3):345-348.

Ahmad, M., J. A. Bhatti, M. Abdullah, R. Ullah., Q. Ain., M.S. Hasni., M. Ali., A. Rashid., I., Qaisar., G. Rashid, and R. Uddin (2019). Different ambient management intervention techniques and their effect on milk production and physiological parameters of lactating Nili-Ravi buffaloes during hot dry summer of subtropical region. Trop. Anim. Health. Prod. 51(4): 911-918. doi:10.1007/s11250-018-1774-5
Anitha, A., K.S. Rao, J. Suresh, P.R.S. Moorthy, and Y.K. Reddy (2011). A body condition score (BCS) system in Murrah buffaloes. Buff. Bull. 30(1):7999.

AOAC (2005). Official methods of analysis of the association of official analytical chemists $\left(18^{\text {th }}\right.$ Ed.). Arlington, VA: the Association. .

Ayaşan, T., H. Hizli, , E. Yazgan., U. Kara, and K. GÖK (2011). The effect of somatic cell count on milk urea nitrogen and milk composition. Kafkas Univ. Vet. Fac. J. 17 (4): 659-662.

Ayaşan T, A. Asarkaya., H. Hizli, K. GÖK, A. Tekgül., E. Karakozak., U. Kara, MS Seğmenoğlu., S. Çoban., H. Mutlu, and N. Kiliçalp (2012-a). The effect of body condition score on embryo quality of Holstein cows. Kafkas Univ. Vet. Fac. J. 18 (1): 91-94.

Ayaşan, T., E. Yazgan, and A. Asarkaya (2012-b). The effect of body condition score on milk composition. Erciyes Ün. Vet. Fak. Derg., 9(2): 89-93

Ballou, M.A., R.C. Gomes, S.O. Juchem, and E.J. DePeters (2009). Effects of dietary supplemental fish oil during the peripartum period on blood metabolites and hepatic fatty acid compositions and total triacylglycerol concentrations of multiparous Holstein cows. J. Dairy Sci. 92(2):657-669.

Bayemi, P.H., E.C. Webb, J.N. Mbanya, D. Cavestany, M.J. Byrant, and V.M. Nsonga (2008). Effect of 
pre-partum feed supplementation on post-partum ovarian activity, milk production and calf growth of dairy cattle of small scale dairy systems of western highlands of Cameroon. PhD Thesis, Dept. Anim. Wildlife. Sci. Uni. Pretoria. PP38,164 . .

Beyero, N., V. Kapoor, and B.S. Tewatia (2015). Effect of different roughage: concentrate ratio on milk yield and its fatty acid profile in dairy cows. J. Bio. Agric. Health. 5(13):176-185.

Cardoso, F.C., S.J. LeBlanc, M.R. Murphy, and J.K. Drackley (2013). Prepartum nutritional strategy affects reproductive performance in dairy cows. J. Dairy Sci. 96(9):5859-5871.

Cam, M.A, A.V. Garipoglu1, and K. Kirikci (2018). Body condition status at mating affects gestation length, offspring yield and return rate in ewes. Arch. Anim. Breed. 61(2): 221-228.

Chagas, L.M., J.J. Bass, D. Blache, C.R. Burke, J.K. Kay, D.R. Lindsay, M.C. Lucy, G.B. Martin, S. Meier, F.M. Rhodes, J.R. Roche., W.W. Thatcher, and R. Webb (2007). Invited Review: New Perspectives on the Roles of Nutrition and Metabolic Priorities in the Subfertility of highProducing Dairy Cows. J. Dairy Sci. 90(9):40224032.

de Feu, M.A., A.C.O. Evans, P. Lonergan, and S.T. Butler (2009). The effect of dry period duration and dietary energy density on milk production, bioenergetic status, and postpartum ovarian function in Holstein-Friesian dairy cows. J. Dairy Sci. 92(12):6011-6022.

Delfino, N.C., L.F.A. Bulcão, H.D.R. Alba, M.X.S. Oliveira, F.P.S. Queiroz, G.G.P. Carvalho, F.P. Rennó, and J.E.F. Júnior (2018). Influence of body condition score at calving on the metabolic status and production performance of Murrah buffaloes (Bubalus bubalis) during the transition period. Asian-Australasian J. Anim. Sci. 31(11): 1756-1765.

Duske, K., H.M. Hammon, A.K. Langhof., O. Bellmann, B. Losand, K. Nurnberg, G. Nurnberg, H. Sauerwein, H.M. Seyfert., and C.C. Metges (2009). Metabolism and lactation performance in dairy cows fed a diet containing rumen-protected fat during the last twelve weeks of gestation. J. Dairy Sci. 92(4):1670-1684.

Gaafar, H.M.A., M. El-Din, M.I. Basiuoni, and K.F.A. ElRiedy (2009). Effect of concentrate to roughage ratio and baker's yeast supplementation during hot season on performance of lactating buffaloes. Czech J. Anim. Sci. 42(4):188-195.

Galic, A. (2017): Determination of the body condition score and its relationship with milk yield in Turkish Holstein cows. J. Agri. Sci. 23(4): 464471.
Gheise, N.J.E., A. Riasi, A.Z. Shahneh, P. Celi, and S.M. Ghoreishi (2017). Effect of pre-calving body condition score and previous lactation on BCS change, blood metabolites, oxidative stress and milk production in Holstein dairy cows. Italian J. Anim. Sci. 16(3): 474-483.

Holcomb, C.S., H.H. Van-Horn., H.H. Head, M.B. Hall, and C.J. Wilcox (2001). Effects of prepartum dry matter intake and forage percentage on postpartum performance of lactating dairy cows. J. Dairy Sci. 84(9):2051-2058.

Houghton, P.L., R.P. Lemenager, L.A. Horstman, K.S. Hendrix, and G.E. Moss (1990). Effects of body composition, pre- and post-partum energy level and early weaning on reproductive performance of beef cows and preweaning calf gain. J. Anim. Sci. 68(5):1438-1446.

Janovick, N.A., Y.R. Boisclair., and J.K. Drackley (2011). Prepartum dietary energy intake affects metabolism and health during the periparturient period in primiparous and multiparous Holstein cows. J. Dairy Sci. 94(3):1385-1400.

Knop, R. and H. Cernescu (2009). Effects of negative energy balance on reproduction in dairy cows. Lucrări Stiin. Med. Vet. 42(2):198-205.

Lalman, D.L., J.E. Williams, B.W. Hess, M.G. Thomas, and D.H. Leisler (2000). Effect of dietary energy on milk production and metabolic hormones in thin, primiparous beef heifers. J. Anim. Sci. 78(3):530-538

Little, M.W., N.E. O'Connell, M.D. Welsh, F.J. Mulligan, and C.P. Ferris (2017). Concentrate supplementation of a diet based on mediumquality grass silage for 4 weeks prepartum: Effects on cow performance, health, metabolic status, and immune function. J. Dairy Sci. 100(6):4457-4474.

Meeske, R., A. Rothauge, G.D.V.D. Merwe, and J.F. Greyling (2006). The effect of concentrate supplementation on the productivity of grazing Jersey cows on a pasture-based system. S. Afr. J. Anim. Sci. 36(2):105-110.

Mithuna, K.V., K.C. Veeranna, S.W. Ruban, B. Ramachandra, M.M. Appannavar, and M.D. Suranagi (2015). Effect of pre partum supplementation on certain characteristics of dam and calf in local buffaloes under mixed farming system. Buff. Bull. 34(3): 339-345.

Neglia, G., A. Balestrieri, B. Gasparrini, M.I. Cutrignelli, G. Bifulco, A. Salzano, R. Cimmino, E. Varricchio, M.J. D’Occhio, and G. Campanile (2014). Nitrogen and phosphorus utilisation and excretion in dairy buffalo intensive breeding. Ital. J. Anim. Sci. 13(4):3362. 
Naqvi, A., and S.A. Shami (1999). Factors affecting birth weight in Nili-Ravi buffalo calves. Pakistan Vet. J. 19 (3): 119-122.

ORIC. (2014). Ethical guidelines for handling research animals available at: http://www.uvas.edu.pk/doc/directorates/2014/R esearch/Guidelines-Protocols.pdf

Pasha, T.N. (2013). Prospects of nutrition and feeding for sustainable buffalo production. Buffalo. Bull.32(Special Issue1):91-110.

Patton, J., D.A. Kenny, S. McNamara, J.F. Mee, F.P. O’Mara, M.G. Diskin, and J.J. Murphy (2007). Relationships among milk production, energy balance, plasma analytes, and reproduction in Holstein-Friesian cows. J. Dairy Sci. 90(2): 649658.

Paul, S.S., A.B. Mandal, and N.N. Pathak (2002). Feeding standards for lactating riverine buffaloes in tropical conditions. J. Dairy Res. 69(2):173-180.

Pereira L.L., A.P. Ferreira, W.G. Vale, L.R. Serique, K. Neves, A.C. Morini, B.M. Monteiro, and A. Minervino (2018). Effect of body condition score and reuse of progesterone- releasing intravaginal devices on conception rate following timed artificial insemination in Nelore cows. Reprod. Dom. Anim. 53(3) :624-628.

Qureshi, M.S., G. Habib, H.A. Samad, M.M. Siddiqui, N. Ahmad, and M. Syed (2002). Reproductionnutrition relationship in dairy buffaloes. Effect of intake of protein, energy and blood metabolites levels. Asian-australas. J. Anim. Sci. 15(3):330339.

Ryan, G., J.J. Murphy, S. Crosse, and M. Rath (2003). The effect of pre-calving diet on post-calving cow performance. Livestock Prod. Sci. 79(1): 61-71.

Samuel, T. (2016). Review on: How Does Pre-Calving Nutrition Interact with Post-Calving Nutrition to Affect Milk Production and Changes in Body Condition of Cows?. European J. Appl. Sci. 8 (6): 330-336.

Stockdale, C.R. (2005). Investigating the interaction between body condition at calving and precalving energy and protein nutrition on the early lactation performance of dairy cows. Australian J. Exp. Agri. 45(12): 1507-1518. doi: 10.1071/EA04104

Rico, D.E., Y. Ying, and K.J. Harvatine (2014). Effect of a high-palmitic acid fat supplement on milk production and apparent total-tract digestibility in high- and low-milk yield dairy cows. J. Dairy Sci. 97(6):3739-3751.

Roche, J. R., S. Meier, A. Heiser, M. D. Mitchell, C.G. Walker, M.A. Crookenden, M.V. Riboni, J.J. Loor, and J.K. Kay.(2015). Effects of precalving body condition score and prepartum feeding level on production, reproduction, and health parameters in pasture-based transition dairy cows. J. Dairy Sci. 98(10) :7164-7182

Sarwar, M., M.A. Khan, M. Nisa, S.A. Bhatti, and M.A. Shahzad (2009). Nutritional management for buffalo production. Asian-australas. J. Anim. Sci. 22(7):1060-1068.

SAS University Edition (2018). SAS Institute Inc., Cary, North Carolina, USA. Available from: https://www.sas.com/en_us/software/universitye dition.html.

Singh, J., B. Singh, M. Wadhwa, and M.P.S. Bakshi (2003). Effect of level of feeding on the performance of crossbred cows during pre- and post-partum periods. Asian-australas. J. Anim. Sci. 16(12):1749-1754.

Singh, R.R., T. Dutt, A.B. Mandal, H.C. Joshi, H.N. Pandey, and M. Singh (2009). Effect of body condition score on blood metabolite and production performance in crossbred dairy cattle. Indian J. Anim. Res. 79(6):629-635.

Straten, M.V., N.Y. Shpigel, and M. Friger (2009). Associations among patterns in daily body weight, body condition scoring, and reproductive performance in high-producing dairy cows. J. Dairy Sci. 92(9):4375-4385.

Talib, C. and T. Herawati (2014). Strategies for increasing Buffalo productivity through improvement in feed and genetic. Indonesian Bull. Anim. Vet. Sci. 24(2): 83-96.

Tyrrell, H.F. and J.T. Reid (1965). Prediction of the energy value of cow's milk. J. Dairy Sci. 48(9):1215-1223.

Tanemura, K., T. Ohtaki, M. Ono, and S. Tsumagari, (2016). Development of ovarian diseases in dairy cows with a history of fatty liver, and their prognosis. J. Vet. Med. Sci. 78(5): 755-760.

Van Soest, P.J., J.B. Robertson, and B.A. Lewis (1991). Methods for dietary fibre, neutral detergent fibre and non-starch polysaccharides in relation to animal nutrition. J. Dairy Sci. 74(10):3583-3597.

Wanapat,M., S. Kang and K. Phesatcha (2013). Enhancing Buffalo Production Efficiency through Rumen Manipulation and Nutrition. Buffalo Bull. 32 (Special Issue 1): 258-275.

Yi, X.W., F. Yang, J.X. Liu, and J.K. Wang (2015). Effects of replacement of concentrate mixture by broccoli byproducts on lactating performance in dairy cows. Asian-australas. J. Anim. Sci. 28(10):1449-1453.

Zhang, Q., H. Su, F. Wang, Z. Cao, and S. Li (2015). Effects of energy density in close-up diets and postpartum supplementation of extruded full-fat soybean on lactation performance and metabolic and hormonal status of dairy cows. J. Dairy Sci. 98(10):1-16. http://dx.doi.org/10.3168/jds.20149112. 